\title{
Pengaruh Arus Kas Bebas dan Profitabilitas terhadap Kebijakan Utang
}

\author{
Wati Aris Astuti \\ Universitas Komputer Indonesia \\ J1. Dipatiukur No. 114-116, Bandung \\ E-Mail:watiarisastuti@yahoo.com \\ Nurlaelasari \\ Universitas Komputer Indonesia \\ J1. Dipatiukur No. 114-116, Bandung
}

\begin{abstract}
The decision to select the best source of funding for companies requiring careful analysis of company financial managers. Debt policyis one ofthe important funding decisions for companies that must always be considered so that the company's financial statements to be optimal. Financial statements that will either enhance the reputation of the company that created the trust all stakeholders such as investors. Free cash flow and profitability is one of the ratios used to measure the financial performance of the company. On the basis of the phenomenon of the study aims to determine how much influence the free cash flow and profitability to debt policy on PT Intraco Penta Tbk (PT Inta).The method used in this research is descriptive and verification methods with quantitative approaches. The data used is the annual financial report of PT Inta for 7 years, from 2005 until 2011. The test statistic used is the calculation of Pearson correlation, multiple linear regression analysis with the classical assumptions. Results of analysis variables free cash flow and profitability have a significant effect and has a strong relationship with the positive direction of the debt policy on PT Intraco Penta Tbk.
\end{abstract}

Keywords: free cash flow, profitability, debt policy.

\begin{abstract}
ABSTRAK
Keputusan untuk memilih sumber pendanaan yang paling baik bagi perusahaan memerlukan analisa seksama dari manajer keuangan perusahaan. Kebijakan utang merupakan salah satu keputusan pendanaan yang penting bagi perusahaan yang harus selalu dipertimbangkan agar laporan keuangan perusahaan menjadi optimal. Laporan keuangan yang baik akan meningkatkan reputasi perusahaan hal tersebut menciptakan kepercayaan semua pihak terkait misalnya investor. Arus kas bebas dan profitabilitas merupakan salah satu rasio yang digunakan perusahaan untuk mengukur kinerja keuangan.Atas dasar fenomena penelitian ini bertujuan untuk mengetahui seberapa besar pengaruh arus kas bebas dan profitabilitas terhadap kebijakan utang pada PT Intraco Penta Tbk (PT Inta). Metode yang digunakan dalam penelitian ini adalah metode deskriptif dan verifikatif dengan pendekatan kuantitatif. Data yang digunakan adalah data laporan keuangan tahunan PT Inta selama 7 tahun dari tahun 2005 samapi dengan tahun 2011. Pengujian statistik yang digunakan adalah perhitungan korelasi Pearson, analisis regresi linier berganda dengan asumsi klasik. Hasil peneletian menunjukkan variabel arus kas bebas dan profitabilitas memiliki pengaruh yang signifikan dan memiliki hubungan yang kuat dengan arah positif terhadap kebijakan utang pada PT Intraco Penta Tbk.
\end{abstract}

Kata Kunci: arus kas bebas, profitabilitas, kebijakan utang. 


\section{PENDAHULUAN}

Perusahaan yang sedang berkembang membutuhkan modal yang lebih besar. Modal tersebut dapat diperoleh dari utang (debt) atau modal sendiri. Keputusan untuk memilih sumber pendanaan yang paling baik bagi perusahaan memerlukan analisa seksama dari manajer keuangan perusahaan. Keputusan pendanaan sangat menentukan kemampuan perusahaan dalam melakukan aktivitas operasinya dan berpengaruh terhadap risiko perusahaan itu sendiri. Banyak perusahaan yang sukses dan berkembang akibat dapat mengambil keputusan pendanaan, akan tetapi banyak juga perusahaan yang jatuh kedalam kebangkrutan akibat banyak utang dan terbelit bunga (Steven dan Lina, 2011).

Penggunaan utang sebagai alat untuk mengatasi konflik keagenan tidak berarti membuat manajemen dapat mengakses utang sebesar-besarnya. Jumlah utang yang terlalu tinggi akan memunculkan financial distress dan menurunkan nilai perusahaan Maka menejer perusahaan harus pintar serta mampu mengendalikan utang.

Esensi dari balancing theory adalah menyeimbangkan manfaat dan pengorbanan yang timbul sebagai akibat dari penggunaan utang. Teori ini menyatakan bahwa perusahaan harus bisa menyeimbangkan komposisi utang dalam kombinasi struktur modalnya sehingga akan diperoleh komposisi utang dan saham yang optimal dengan analisis perhitungan keuangan yang tepat. Beberapa perusahaan mempergunakan kewajiban lancar sebagai sumber utama pendanaan aktiva lancarnya, sedangkan yang lain sangat tergantung pada utang jangka panjang dan ekuitas (Brigham dan Houston, 2011). Keputusan tentang struktur modal melibatkan analisis "trade-off" antara risiko dan keuntungan (Melinda dan Cristina, 2009). Penggunaan utang meningkatkan risiko perusahaan tetapi juga meningkatkan keuntungan perusahaan (Atmaja, 2008:274).

Pada tingkat profitabilitas yang rendah, perusahaan menggunakan utang untuk membiayai operasional, sebaliknya pada tingkat profitabilitas yang tinggi, perusahaan mengurangi penggunaan utang (Ismiyanti dan Hanafi, 2004). Hal ini disebabkan karena perusahaan diasumsikan mengalokasikan sebagian besar keuntungan pada laba ditahan sehingga mengandalkan sumber dana internal dan menggunakan utang dalam tingkat yang rendah, tetapi saat mengalami profitabilitas yang rendah, perusahaan akan menggunakan utang yang tinggi sebagai mekanisme transfer kekayaan antara kreditur kepada prinsipal.

Daya menghasilkan laba (potential earning power) juga signifikan bagi para pemakai laporan keuangan lainnya seperti pemasok dan serikat pekerja, yang berkepentingan dalam membina hubungan yang berkesinambungan dengan perusahaan yang sehat secara finansial. Kesehatan keuangan perusahaan tergantung pada daya laba di masa yang akan datang.

Dalam memaksimumkan keuntungan selalu ada pertukaran dengan risiko. Semakin besar risiko yang dihadapi, akan semakin besar pula keuntungan yang diharapkan. Seumpama kita diminta memilih di antara dua proyek yang mempunyai risiko yang sama, kita akan memilih proyek yang akan memberikan imbalan atau perolehan (return) yang lebih besar.

Arus kas bebas positif mencerminkan jumlah yang tersedia bagi aktivitas bisnis setelah penyisihan untuk pendanaan dan investasi yang diperlukan untuk mempertahankan kapasitas produksi pada tingkat sekarang. Pertumbuhan dan fleksibilitas keuangan bergantung pada ketersediaan arus kas bebas, John J. Wild, K. R. Subramanyam, Robert F. Halsey (2004).

Harus diakui bahwa jumlah pengeluaran modal untuk mempertahankan kapasitas produksi umumnya tidak diungkapkan. Jumlah ini disajikan sebagai bagian total pengeluaran modal yang diungkapkan, namun meliputi pengeluaran kapasitas produksi pemisahan dua komponen pengeluaran modal ini sulit dilakukan. laporan arus kas jarang memisahkan pengeluaran modal menjadi komponen untuk mempertahankan dan komponen untuk ekspansi, John J. Wild, K. R. Subramanyam, Robert F. Halsey (2004).

Keberadaan arus kas bebas dalam perusahaan berpotensi untuk menimbulkan konflik keagenan antara pemegang saham dan manajer. Pemegang saham menginginkan agar sisa dana dibagikan kepada mereka dalam bentuk dividen. Sedangkan manajer lebih menyukai untuk menginvestasikan dana yang tersedia pada proyek-proyek yang menguntungkan dengan harapan dapat menambah insentif bagi manajer di masa yang akan datang (Fitriyah dan Hidayat, 2011).

Jensen (1986) berpendapat bahwa salah satu solusi untuk mengurangi biaya keagenan yang timbul akibat konflik keagenan ini adalah dengan utang. Dengan adanya utang, manajer termotivasi untuk bekerja dengan lebih efisien, sehingga dapat meningkatkan efisiensi organisasi perusahaan. Pengaruh ini disebut dengan control hypothesis. 
Adapun fenomena khusus yang dikutip dari economy.okezone.com - Oktober 2010, PT Intraco Penta Tbk (INTA) yang merupakan perusahaan industri alat-alat berat pertambangan, di Kuartal III-2010 mengalami kenaikan utang bank jangka pendek yaitu sebesar 76,7 persen dari periode yang sama di tahun lalu sebesar Rp 43,13 miliar menjadi Rp 76,29 miliar. Kenaikan utang jangka pendek tersebut mengakibatkan jumlah kewajiban lancar perseroan mengalami kenaikan 55,8 persen dari Rp 505,5 miliar di Kuartal III-2009 menjadi Rp 787,7 miliar. Adapun jumlah kewajiban tidak lancar perseroan juga mengalami kenaikan dari Rp 244,6 miliar di Kuartal ketiga tahun lalu menjadi Rp 274,5 miliar atau meningkat 12,22 persen, sehingga total kewajiban perseroan mengalami peningkatan 41,5 persen menjadi $\mathrm{Rp} 1.06$ triliun dibandingkan Rp 750,2 miliar.

Debt to equity ratio (DER ratio) pada PT Intraco Penta Tbk (INTA) juga mengalami perubahan di tahun 2010, yaitu mengalami kenaikan dibandingkan pada tahun 2009 yaitu dari 1,91 persen menjadi 2,91persen. Peningkatan tersebut juga dampak dari aksi korporasi dimana peningkatan yang signifikan pada pos utang sewa pembiayaan, dimana sebagai perusahaan jasa, banyak memanfaatkan jasa pembiayaan untuk perolehan aset tetap disewakan, ujar Direktur Keuangan INTA Fred L. Manibog kepada BEI seperti dikutip wartawan dalam keterbukaan informasi di BEI, Jakarta, Senin (18/10/2010). Peningkatan lainnya terlihat dari profitabilitas yang baik atau meningkat. Peningkatan ini ditunjukan oleh kenaikan return on equity ratio ( $\mathrm{ROE}$ ratio), yaitu di tahun 2010 mengalami kenaikan dibandingkan tahun 2009 dari 10,48 persen menjadi 20,16 persen.

Tabel 1. Besarnya Profitabilitas (ROE), Kebijakan Utang (DER) PT Intraco Penta Tbk

\begin{tabular}{|c|c|c|c|}
\hline \multirow{2}{*}{$\begin{array}{c}\text { Tahun } \\
2005\end{array}$} & $\begin{array}{c}\text { Rasio Utang (DER) } \\
(\%)\end{array}$ & \multicolumn{2}{|c|}{$\begin{array}{c}\text { Profitabilitas (ROE) } \\
(\%)\end{array}$} \\
\hline & 1.80 & 5.79 & - \\
\hline 2006 & 1.68 & 2.28 & \\
\hline 2007 & 1.70 & 2.97 & \\
\hline 2008 & 2,46 & 6,98 & \\
\hline 2009 & 1,91 & 10.48 & \\
\hline 2010 & 2,91 & 20.16 & \\
\hline 2011 & 5,96 & 15.75 & \\
\hline
\end{tabular}

Sumber :www.idx.co.id, diolah
Dari Tabel 1. profitabilitas PT Intraco Penta Tbk yang ditunjukan oleh ROE, pada tahun 2010 mengalami peningkatan dibandingkan tahun sebelumnya tetapi rasio utang (DER) ikut mengalami peningkatan. Peningkatan tersebut disebabkan oleh peningkatan dana pinjaman selama tahun berjalan, juga peningkatan tersebut akibat dari perusahaan yang tidak menggunakan profitnya untuk membayar utang tetapi menggunakan profitnya untuk menambah arus kasnya. Hal tersebut bertolak belakang dengan teori yang dikemukakan oleh Sugiarto (2003) menyatakan bahwa semakin tinggi rasio profitabilitas akan diikuti oleh penurunan rasio utang perusahaan. Semakin tinggi profitabilitas berarti semakin besar pula kemampuan perusahaan dalam mengembalikan utang.

Arus kas bebas perusahaan mengalami penurunan tetapi rasio utang (DER) meningkat pada tahun 2010. Arus kas bebas adalah arus kas yang tersedia untuk dibagikan kepada investor sehingga investor tidak mendapatkan apa-apa, bahkan harus memberikan lebih banyak uang untuk menjaga agar usahanya tetap berjalan. Investor memberikan sebagian besar dana yang dibutuhkan sebagai utang (Brigham dan Houston, 2010). Perusahaan yang memiliki arus kas besar/tinggi akan memonitor perilaku manajer dalam melakukan investasi dengan menambah utang, sehingga manejer tidak akan membuangbuang kas bebas perusahaan untuk investasi yang tidak menguntungkan. Semakin besar arus kas bebas perusahaan maka akan mempunyai level utang yang tinggi. Sebaliknya semakin kecil arus kas bebas maka level utang perusahaanpun akan rendah, karena perusahaan tidak melakukan penambahan utang untuk investasi.

Perusahaan yang memiliki free cash flow mempunyai dua pilihan dalam memperlakukan kas yaitu pertama, membayar dividen kepada pemegang saham dan kedua, meinvestasikan pada projek-projek yang mempunyai nilai sekarang bersih misalnya membeli aset-aset tetap. Analisis free cash flow dimulai dengan kas bersih yang disediakan oleh aktivitas operasi dan berakhir pada arus kas bebas yang dihitung sebagai kas bersih yang disediakan oleh aktivitas operasi dikurangi pengeluaran modal dan dividen. Free cash flow adalah jumlah arus kas dikuesionerkan perusahaan untuk membeli investasi tambahan, melunasi utangnya, membeli saham treasuri atau menaikkan likuiditasnya, (Keiso et al., 2002). 
Tujuan utama dari dari operasi perusahaan adalah untuk mengahasilkan laba. Dalam partnership dan proprietorship (kepemilikan), pemilik dapat menggambarkan laba dari entitas bisnis untuk meningkatkan kekayaan bersih mereka atau dapat meninggalkan bisnisnya untuk memperluasnya. Dalam penyatuan perusahaan, laba dapat dikeluarkan dalam deviden atau diperoleh kembali dalam perusahaan bisnis, peningkatan laba lebih lanjut, dan meningkatkan nilai dari investasi ekuitas pemilik diperusahaan. Kreditor perusahaan juga ingin meningkatkan laba bisnis, karena semakin tinggi labanya, kurangnya risiko terhadap mereka sebagai pemilik dana. Oleh karenanya, satu dari fungsi tugas manajemen adalah untuk menjamin kontinuitas profitabilitas dari perusahaan.

Aktiva yang dimilki oleh sebuah perusahaan jasa dapat didanai oleh sumber luar (utang) maupun dari modal sendiri. Debt Equity Ratio menggambarkan hubungan di antara kedua sumber pendanaan aktiva tersebut.

Utang perusahaan berkaitan sangat erat dengan struktur modal suatu perusahaan.banyak faktor yang mempengaruhi keputusan perusahaan dalam melakukan pendanaan di antaranya komposisi struktur modal perusahaan. Komposisi modal suatu perusahaan yang di dalamnya terdapat kepemilikan menejerial tentu akan mempengaruhi keputusan pendanaan yang akan dilakukan perusahaan. Pengambilan kebijakan tersebut sangat erat kaitannya dengan keputusan yang diambil oleh manajemen perusahaan yang sangat pekat dengan masalah keagenan (agency theory) (Steven dan Lina, 2011).

Dalam praktik sangat sulit menentukan titik struktur modal yang optimal. Bahkan untuk membuat suatu range untuk struktur modal yang optimal pun sangat sulit. Oleh karena itu, kebanyakan perusahaan hanya memperhatikan apakah perusahaan terlalu banyak menggunakan utang atau tidak. Sebaiknya perusahaan lebih memfokuskan diri pada suatu tingkat utang yang hati-hati (prudent) daripada berusaha mencari tingkat utang yang optimal karena semakin besar .Tingkat utang yang prudent harus dapat memanfaatkan keuntungan dari pengguna utang (Atmaja, 2008:274).

Berdasarkan pada latar belakang yang dipaparkan tersebut maka penelitian ini diberi judul "Pengaruh Arus Kas Bebas dan Profitabilitas terhadap Kebijakan Utang Pada PT Intraco Penta Tbk"

\section{METODE}

Metode penelitian yang digunakan adalah metode deskriptif verifikatif. Metode tersebut digunakan untuk menguji pengaruh dari Arus Kas Bebas dan Profitabilitas terhadap kebijakan utang, dengan paradigma penelitian seperti digambarkan pada Gambar 1.

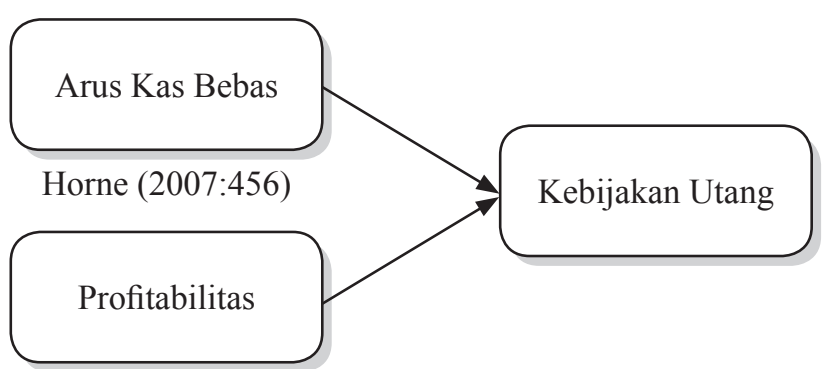

Atmaja (2008:274)

Gambar 1. Paradigma Penelitian

Menurut Jerry, Kieso, dan Paul (2008) arus kas bebas yaitu menggambarkan jumlah kas yang tersisa dari operasi setelah penyesuaian untuk pembelian asset tetap (pengeluaran modal) dan pembayaran deviden. Menurut Brigham dan Houston (2010:109) free cash flow adalah arus kas yang benar-benar tersedia untuk dibayarkan kepada seluruh investor (pemegang saham dan pemilik utang) setelah perusahaan menempatkan seluruh investasinya pada aktiva tetap, produk-produk baru dan modal kerja yang dibutuhkan untuk mempertahankan operasi yang sedang berjalan. Dari kedua definisi tersebut dapat disimpulkan bahwa arus kas bebas (free cash flow) adalah arus kas yang tersedia untuk didistribusikan kepada seluruh investor (pemegang saham dan pemilik utang) setelah perusahaan menempatkan seluruh investasinya dan juga yang diperlukan untuk mempertahankan kelangsungan usahanya, dan sebagai alat untuk mengukur kemampuan perusahaan untuk terlibat dalam jangka panjang peluang investasi yang disediakan oleh aktivitas operasi dan berakhir pada arus kas bebas (free cash flow) yang dihitung sebagai kas bersih yang disediakan oleh aktivitas operasi dikurangi pengeluaran modal dan dividen. Free cash flow dapat dirumuskan sebagai berikut:

\section{FCF $=$ Cash Flow From Operations (Operating Cash)-Capital Expenditure}


Menurut Brigham dan Houston (2010:107) profitabilitas adalah hasil akhir dari sejumlah kebijakan dari keputusan yang dilakukan oleh perusahaan. Rasio-rasio yang telah dibahas sejauh ini dapat memberikan petunjuk-petunjuk yang berguna dalam menilai keefektifan dan operasi sebuah perusahaan, tetapi rasio profitabilitas (profitability ratio) akan menunjukan kombinasi efek dari likuiditas, manajemen aktiva, dan utang pada hasilhasil operasi. Menurut Harahap (2009) profitabilitas yaitu menggambarkan kemampuan perusahaan mendapatkan laba melalui semua kemampuan dan sumber yang ada seperti kegiatan penjualan, kas, modal, jumlah karyawan, jumlah cabang, dan sebagainya. Dari definisi tersebut dapat disimpulkan bahwa profitabilitas adalah hasil akhir dari sejumlah kebijakan keputusan perusahaan yang digambarkan oleh return on investment yang dapat menunjukan kombinasi efek dari likuiditas, manajemen aktiva, dan utang pada hasil-hasil operasi.

Menurut Harahap (2009) pengembalian atas modal merupakan salah satu indikator atas kekuatan perusahaan dalam jangka panjang. Rasio ini menunjukan berapa persen diperoleh laba bersih bila diukur dari modal pemilik. Semakin besar atau meningkat rasio ini maka semakin bagus untuk perusahaan. Rumus dari Return on equity (ROE) yaitu sebagai berikut:

$$
\text { Return On Equity }=\frac{\text { Laba Bersih }}{\text { Rata-Rata Modal (Equity) }}
$$

Menurut Ikhsan (2009:105), Debt Equity Ratio atau rasio hutang dapat dirumuskan sebagai berikut:

Debt Equity Ratio $=\frac{\text { Total Hutang }}{\text { Total Modal }}$

Total hutang yang dimaksud dalam rumus perhitungan tersebut adalah seluruh total hutang perusahaan, yaitu hasil penjumlahan utang jangka pendek dan utang jangka panjang dalam satu periode akuntansi. Sedangkan total modal adalah seluruh total modal perusahaan, yaitu hasil penjumlahan modal sendiri dan modal saham yang ada

\section{Populasi dan Penarikan Sampel}

Penelitian dilakukan dengan objek penelitain adalah perusahaan PT Intraco Penta Tbk yang sudah terdaftar di Bursa Efek Indonesia sejak tahun 1993 sampai dengan sekarang. Data yang dipergunakan adalah data dalam laporan keuangan yaitu Laporan Laba Rugi, Neraca, dan Laporan Arus Kas tahunan selama 7 tahun terakhir yaitu dari tahun 2005 sampai dengan 2011.

\section{HASIL}

Berdasarkan data yang terdapat pada Laporan Keuangan PT Intraco Penta Tbk, yaitu Laporan Laba Rugi, Neraca, dan Laporan Arus Kas dari tahun 2005 sampai dengan tahun 2011, maka diperoleh gambaran perkembangan operating cash, capital expenditure, arus kas bebas, laba bersih, total modal, profitabilitas (ROE), total utang, total modal dan DER, seperti terlihat pada Tabel 2. sampai dengan Tabel 4.

Dengan menggunakan data-data yang disajikan dalam Tabel 2. sampai dengan Tabel 4. selanjutnya dilakukan pengolahan data dnegan teknik regresi. Adapun hasil regresinya beserta pengujiannya dapat dilihat pada Tabel 5. sampai dengan Tabel 13.

Tabel 2. Perkembangan Arus Kas Bebas pada PT Intraco Penta Tbk Tahun 2005-2011

\begin{tabular}{rrrr}
\hline Tahun & Operating Cash & $\begin{array}{c}\text { Capital } \\
\text { Expenditure }\end{array}$ & Arus Kas Bebas \\
\hline 2005 & $2,897,104,186$ & $-2,481,411,146$ & $5,378,515,332$ \\
2006 & $-54,476,324,766$ & $-4,136,220,914$ & $-50,340,103,852$ \\
2007 & $34,794,324,996$ & $252,959,164$ & $34,541,365,832$ \\
2008 & $17,236,305,172$ & $17,980,584,325$ & $-744,279,153$ \\
2009 & $107,682,723,082$ & $-4,927,226,419$ & $112,609,949,501$ \\
2010 & $70,181,186,764$ & $227,671,435,961$ & $-157,490,249,197$ \\
2011 & $923,613,000,000$ & $-243,695,211,048$ & $1,167,308,211,048$ \\
\hline
\end{tabular}

Tabel 3. Perkembangan Profitabilitas (ROE) pada PT Intraco Penta Tbk tahun 2005-2011

\begin{tabular}{lllr}
\hline Tahun & Laba Bersih & Total Modal & ROE (\%) \\
\hline 2005 & $17,997,762,600$ & $315,449,877,028$ & 5.71 \\
2006 & $7,065,909,337$ & $310,575,717,346$ & 2.28 \\
2007 & $9,513,887,731$ & $320,089,605,077$ & 2.97 \\
2008 & $22,943,741,774$ & $328,623,475,813$ & 6.98 \\
2009 & $37,473,252,355$ & $357,456,611,288$ & 10.48 \\
2010 & $83,081,383,677$ & $412,045,570,300$ & 20.16 \\
2011 & $84,529,000,000$ & $536,767,000,000$ & 15.75 \\
\hline
\end{tabular}


Tabel 4. Perkembangan Kebijakan Utang pada PT Intraco Penta Tbk Tahun 2005-2011

\begin{tabular}{cllc}
\hline Tahun & Total Utang & Total Modal & DER (kali) \\
\hline 2005 & $572,194,109,574$ & $315,449,877,028$ & 1.81 \\
2006 & $521,270,332,476$ & $310,575,717,346$ & 1.68 \\
2007 & $543,728,031,380$ & $320,089,605,077$ & 1.70 \\
2008 & $808,594,720,711$ & $328,623,475,813$ & 2.46 \\
2009 & $682,054,367,132$ & $357,456,611,288$ & 1.91 \\
2010 & $1,198,084,207,003$ & $412,045,570,300$ & 2.91 \\
2011 & $3,201,151,000,000$ & $536,767,000,000$ & 5.96 \\
\hline
\end{tabular}

Tabel 5. Hasil Estimasi Model Regresi

Coefficients $^{\mathrm{a}}$

\begin{tabular}{llrrrrr}
\hline \multirow{2}{*}{ Model } & \multicolumn{2}{c}{$\begin{array}{l}\text { Unstandardized Standardized } \\
\text { Coefficients }\end{array}$} & \multicolumn{2}{c}{ Coefficients } & \multirow{2}{*}{ Sig. } \\
\cline { 2 - 3 } & B & Std. Error & \multicolumn{1}{c}{ Beta } & & \\
\hline (Constant) & 1.419 & .303 & & 4.690 & .009 \\
1 AKB (milliar) & .003 & .000 & .776 & 6.160 & .004 \\
ROE & .087 & .029 & .377 & 2.987 & .040 \\
\hline
\end{tabular}

a. Dependent Variable: DER

Tabel 6. Hasil Pengujian Asumsi Normalitas

One-Sample Kolmogorov-Smirnov Test

\begin{tabular}{llr}
\hline & Unstandardized Residual \\
\hline $\mathrm{N}$ & & 7 \\
Normal & Mean & $0 \mathrm{E}-7$ \\
Parameters ${ }^{\mathrm{a}, \mathrm{b}}$ & Std. Deviation & .36432748 \\
& Absolute & .235 \\
Most Extreme & Positive & .153 \\
Differences & Negative & -.235 \\
& .623 \\
Kolmogorov-Smirnov Z & .832 \\
Asymp. Sig. (2-tailed)
\end{tabular}

a. Test distribution is Normal.

b. Calculated from data.

Tabel 7. Pengujian Collinearity

Coefficients $^{\mathrm{a}}$

\begin{tabular}{cccc}
\hline \multicolumn{3}{c}{ Model } & \multicolumn{3}{c}{ Coefficients $^{\mathrm{a}}$} \\
\cline { 3 - 4 } & & \multicolumn{2}{c}{ Collinearity Statistics } \\
\hline \multirow{2}{*}{1} & AKB & .884 & 1.131 \\
& ROE & .884 & 1.131 \\
\hline
\end{tabular}

a. Dependent Variable: DER

Tabel 8. Hasil Pengujian Asumsi Heteroskedastisitas

\begin{tabular}{|c|c|c|c|}
\hline \multicolumn{4}{|c|}{ Correlations } \\
\hline & & & absolut_residual \\
\hline \multirow{6}{*}{$\begin{array}{l}\text { Spearman's } \\
\text { rho }\end{array}$} & & Correlation Coefficient & -.250 \\
\hline & AKB & Sig. (2-tailed) & .589 \\
\hline & & $\mathrm{N}$ & 7 \\
\hline & & Correlation Coefficient & .107 \\
\hline & ROE & Sig. (2-tailed) & .819 \\
\hline & & $\mathrm{N}$ & 7 \\
\hline
\end{tabular}

Tabel 9. Hasil Pengujian Autokorelasi

Model Summary ${ }^{b}$

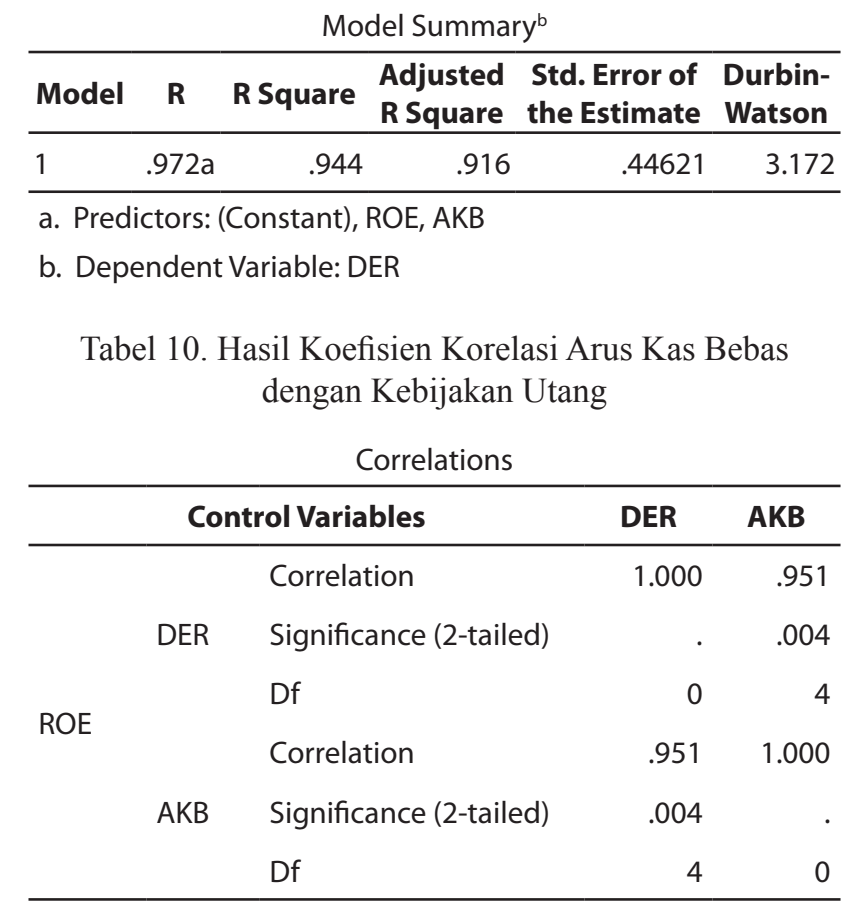

Tabel 11. Hasil Koefisien Korelasi Profitabilitas dengan Kebijakan utang

Correlations

\begin{tabular}{|c|c|c|c|c|}
\hline \multicolumn{3}{|c|}{ Control Variables } & \multirow{2}{*}{$\begin{array}{l}\text { DER } \\
1.000\end{array}$} & \multirow{2}{*}{$\begin{array}{r}\text { AKB } \\
.831\end{array}$} \\
\hline \multirow{6}{*}{ AKB } & \multirow{3}{*}{ DER } & Correlation & & \\
\hline & & Significance (2-tailed) & . & .040 \\
\hline & & Df & 0 & 4 \\
\hline & \multirow{3}{*}{ ROE } & Correlation & .831 & 1.000 \\
\hline & & Significance (2-tailed) & .040 & . \\
\hline & & Df & 4 & 0 \\
\hline
\end{tabular}


Tabel 12. Hasil Pengujian Koefisien Regresi Secara Bersama-sama

\begin{tabular}{lrrrrrr}
\hline \multicolumn{6}{c}{ ANOVA $^{\text {a }}$} \\
\hline & $\begin{array}{c}\text { Sum of } \\
\text { Squares }\end{array}$ & df & $\begin{array}{c}\text { Mean } \\
\text { Square }\end{array}$ & F & Sig. \\
\hline & Regression & 13.385 & 2 & 6.693 & 33.614 & $.003 b$ \\
& Residual & .796 & 4 & .199 & & \\
& Total & 14.182 & 6 & & & \\
\hline
\end{tabular}

a. Dependent Variable: DER

b. Predictors: (Constant), ROE, AKB

Tabel 13. Hasil Koefisien Korelasi Berganda dan Koefisien Determinasi

Model Summary ${ }^{b}$

\begin{tabular}{lcrrrr}
\hline Model & R & R Square & $\begin{array}{r}\text { Adjusted } \\
\text { R Square }\end{array}$ & $\begin{array}{c}\text { Std. Error of } \\
\text { the Estimate }\end{array}$ & $\begin{array}{l}\text { Durbin- } \\
\text { Watson }\end{array}$ \\
\hline 1 & $.972 \mathrm{a}$ & .944 & .916 & .44621 & 3.172 \\
\hline
\end{tabular}

a. Predictors: (Constant), ROE, AKB

b. Dependent Variable: DER

\section{PEMBAHASAN}

\section{Pengaruh Arus Kas Bebas terhadap Kebijakan Utang}

Hasil penelitian menunjukan bahwa arus kas bebas memiliki pengaruh dan hubungan terhadap kebijakan utang pada PT Intraco Penta Tbk. Di mana arus kas bebas memberikan pengaruh yaitu sebesar 90,4\% yang sisanya yaitu sebesar 9,6\% dipengaruhi oleh faktor-faktor lain. Arus kas bebas juga memiliki hubungan dengan kebijakan utang yaitu sebesar 0,951 sisanya arus kas bebas memiliki hubungan dengan variabel lain seperti arus kas operasi dan pengeluaran modal. Arah hubungan positif disini artinya arus kas bebas memiliki hubungan yang sangat kuat dengan kebijakan utang ketika profitabilitas tidak mengalami perubahan. Arah hubungan ini menunjukan bahwa ketika arus kas bebas meningkat, sementara profitabilitas tidakberubah maka kebijakan utang (debt equity ratio) akan naik. Hal ini berarti bahwa apabila arus kas bebas perusahaan naik maka kebijakan utangpun (DER) akan naik dan sebaliknya apabila arus kas bebas rendah maka kebijakan utangpun (DER) akan rendah.

Hal ini sesuai dengan teori yang menyebutkan bahwa semakin besar dan stabil arus kas bebas dimasa datang yang diharapkan perusahaan, semakin besar kapasitas utang perusahaan. Perusahaan dengan sedikit pinjaman dan arus kas bebas yang besar, memiliki kecenderungan untuk tidak terlalu mengawasi pemakaian biaya-biaya yang sebenarnya dapat dikurangi.

Hasil penelitian ini sesuai dengan penelitian Jaggi and A. Gul (1999), penelitian Agrawal, A. dan N. Jayaraman (1994), penelitian Vogt (1994) serta penelitian Indahningrum dan Handayani (2009) yang menunjukkan bahwa variabel Arus Kas Bebas (Free Cash Flow) memiliki pengaruh positif dan signifikan terhadap kebijakan utang. Ketika arus kas bebas (Free Cash Flow) tinggi maka perusahaan cenderung menggunakan utang untuk kegiatan pendanaan perusahaan (Jensen, 1986). Perusahaan yang memiliki arus kas bebas tinggi akan memonitor perilaku manajer dalam melakukan investasi dengan menambah utang, sehingga manajer tidak akan membuang-buang kas bebas perusahaan untuk investasi yang tidak menguntungkan.

\section{Pengaruh Profitabilitas terhadap Kebijakan Utang}

Hasil penelitian menunjukan bahwa profitabilitas memiliki pengaruh dan hubungan dengan kebijakan utang pada PT Intraco Penta Tbk. Di mana profitabilitas memilik pengaruh yaitu sebesar $69,1 \%$ sisanya sebesar 30,9\% dipengaruhi oleh faktor-faktor lain. Profitabilitas juga memiliki hubungan dengan kebijakan utang yaitu sebesar 0,831 sedangkan sisanya profitabilitas memiliki hubungan dengan variabel lain yaitu tingkat suku bunga, laba bersih dan modal. Hubungan positif disini artinya profitabilitas memiliki hubungan yang sangat kuat dengan kebijakan utang ketika arus kas bebas tidak mengalami perubahan. Arah hubungan positif menunjukan bahwa ketika profitabilitas meningkat, sementara arus kas bebas tidak berubah maka kebijakan utang (DER) akan meningkat. Hal ini berarti apabila profitabilitas perusahaan meningkat maka kebijakan utang pun (DER) akan meningkat dan sebaliknya apabila profitabilitas menurun maka kebijakan utangpun (DER) menurun.

Hal tersebut didukung oleh penelitian Hardiningsih dan Meita (2012), Mendell et al. (2006), Gleason et al. (2000), Abor, J. (2005), Soesetio (2007), dan Sjaheen dan Malik (2012) yang menunjukkan bahwa profitabilitas (ROE) memiliki pengaruh signifikan positif terhadap kebijakan utang.Temuan ini mendukung teori keagenan bahwa perusahaan 
mempunyai profit tinggi, untuk menghindari penyalahgunaan dana oleh manajemen, profit dibagi dalam bentuk dividen dan pendanaan menggunakan utang. Perusahaan yang mempunyai profitabilitas yang tinggi menunjukkan bahwa perusahaan tersebut mempunyai kinerja yang baik dan berprospek baik. Tingkat profitabilitas yang tinggi merupakan harapan dari para pemegang saham, dimana keuntungan dibagikan sebagai dividen

\section{Pengaruh Arus Kas Bebas dan Profitabilitas terhadap Kebijakan Utang}

Hasil penelitan menyatakan bahwa kedua variabel independen yaitu arus kas bebas dan profitabilitas secara bersama-sama berpengaruh dan memiliki hubungan yang sangat erat dengan kebijakan utang pada PT Intraco Penta Tbk.

Dengan kata lain kedua variabel independen (arus kas bebas dan profitabilitas) memberikan kontribusi/ pengaruh sebesar 94,4\% dan sisanya sebesar 5,6\% dipengaruhi oleh faktor-faktor lain diluar arus kas bebas dan profitabilitas, seperti kebijakan deviden, investasi, kepemilikan institusional, struktur aset, ukuran perusahaan, dan pertumbuhan perusahaan.

Hal tersebut sesuai dengan penelitian Indahningrum dan Handayani (2009), yaitu menyatakan bahwa arus kas bebas dan profitabilitas memiliki pengaruh terhadap kebijakan utang. Karena keduanya dapatmembantu manajer dalammenentukan atau mengambil keputusan dalam berutang. Apabila arus kas bebas tinggi, manajer mampu meningkatkan utang agar kas bebas perusahaan tidak digunakan untuk investasi yang tidak menguntungkan. Jika profitabilitas tinggi maka manajer dapat meningkatkan utang. Apabila profitabilitas suatu perusahaan tinggi maka akan banyak investor yang tertarik untuk menyimpan modal pada perusahaan.

\section{KESIMPULAN}

Berdasarkan hasil penelitian tentang pengaruh arus kas bebas dan profitabilitas terhadap kebijakan utang pada PT Intraco Penta Tbk menunjukkan bahwa arus kas bebas memiliki pengaruh dan hubungan positif terhadap kebijakan utang pada PT Intraco Penta Tbk. Arus kas bebas juga memiliki hubungan positif dengan kebijakan utang. Profitabilitas memiliki pengaruh dan hubungan positif dengan kebijakan utang pada PT Intraco Penta Tbk. Arus kas bebas dan profitabilitas secara bersama-sama berpengaruh dan memiliki hubungan positif yang sangat erat dengan kebijakan utang pada PT Intraco Penta Tbk.

\section{DAFTAR PUSTAKA}

Abor, J. 2005. The Effect of Capital Structure on Profitability: Empirical Analysis of Listed Firms in Ghana. Journal of Risk Finance, 6(5): 438-45.

Agrawal, A. and N. Jayaraman. 1994. The Dividend Policies of All-Equity Firms: a Direct Test of the Free Cash Flow Theory. Managerial and Decision Economics, 15: 139-148.

Atmaja, Lukas Setia. 2008. Teori dan Praktik Manajemen Keuangan. Yogyakarta: Andi Offset.

Brigham and Houston. 2011. Fundamentals of Financial Management (edisi 11). Jakarta: Salemba Empat.

Fitriyah, Fury K. dan Hidayat, Dina. 2011. Pengaruh kepemilikan Institusional, Set Kesempatan Investasi, Dan Arus Kas Bebas Terhadap Utang. Jurnal Media Riset Akuntansi, 1(1).

Gleason, K. C., L. K. Mathur, and I. Mathur. 2000. The Interrelationship between Culture, Capital Structure, and Performance: Evidence from European Retailers. Journal of Business Research, 50(2): 185-91.

Hardiningsih, Pancawati dan Meita Oktaviani, Rachmawati. 2012. Pengaruh Due Profesional Care, Etika, dan Tenur terhadap Kualitas Audit (Perspektif Expectation Theory). Makalah Seminar. Ikhsan, Arfan. 2009. Akuntansi Manajemen Perusahaan. Yogyakarta: Graha Ilmu.

Indahningrum, Rizkia P., dan Handayani, Ratih. 2009. Pengaruh kepemilikan manajerial, Kepemilikan Institusional, Dividen, Pertumbuhan Perusahaan, Free Cash Flow Dan Profitabilitas Terhadap Kebijakan Utang. Jurnal Bisnis dan Akuntansi, 11(3).

Ismiyanti, Fitri dan Hanafi, Mahmud. 2004. Strukur Kepemilikan, Risiko, dan Kebijakan Keuangan: Analisis Persamaan Simultan. Jurnal Ekonomi dan Bisnis Indonesia, 19(2).

Jaggi, Bikki and A.Gul, Ferdinand. 1999. An Analysis of Joint Effects of Investment Opportunity Set, Free Cash Flows and Size on Corporate Debt Policy. Review of Quantitative Finance and Accounting, 12: 371-381.

Jensen, M. 1986. Agency Costs of Free Cash Flow, Corporate Finance and Takeovers. American Economic Review, 76: 323-339. 
Kieso, Donald E., Jerrry J. Weygandt, and Terry D. Warfield. 2005. Akuntansi Intermediet. Jakarta: Erlangga.

Kieso, Donald, Jerry J. Weygandt, and Paul D. Kimmel. 2008. Pengantar Akuntansi. Jakarta: Salemba Empat.

Melinda, Keul and Cristina, Drumea. 2009. Risk and Profitability as Capital Structure Determinants. 237-241. Steconomice, 3: 237-241.

Mendell, B. C., Sydor, T., and Mishra, N. 2006. Capital structure in the United States Forest Products Industry: The influence of Debt and Taxes. Forest Science, 52(5): 540-548.

Shaheen, Sadia dan Malik, Qaisar Ali . 2012. The Impact of Capital Intensity, Size of Firm And Profitability on Debt In Textile Industry of Pakistan. Interdisicplinary Journal Of Contemporary Reserch In Businnes, 3(10).
Steven dan Lina. 2011. Faktor-Faktor Yang Mempengaruhi Kebijakan Utang Perusahaan Manufaktur. Jurnal Bisnis Dan Akuntansi, 13(3). Soesetio, Yuli. 2007. Kepemilikan Manajerial Dan Institusional, Kebijakan Dividen, Ukuran Perusahaan, Struktur Aktiva Dan Profitabilitas Terhadap Kebijakan Utang. Jurnal Bisnis Dan Akuntansi, 11(3).

Van Horne, James C., and Wachowicz Jr., John M. 2007. Prinsip-Prinsip Manajemen Keuangan. Jakarta: Salemba Empat.

Vogt, S. C. 1994. The Cash Flow/Investment Relationship: Evidence from U.S. Manufacturing Firms. Financial Management, 23(2): 3-20.

Wild, John J., Halsey, Robert. F, and Subramanyam, K. R. 2005. Financial Statement Analysis. McGraw Hill.

Wild, John J., K. R. Subramanyam, dan Robert F. Halsey. 2012. Analisis Laporan Keuangan (edisi ke-8). Jakarta: Salemba Empat. 